\title{
Toxicity of Methanolic Seed Extract of Barringtonia asiatica L. (Kurz) (Lecythidaceae) from Different Place in Indonesia Against Spodotera litura F (Lepidoptera: Noctuidae).
}

\author{
Danar Dono*, Irpan Permana \\ Department of Plant Pests and Diseases, Agriculture Faculty, Universitas Padjadjaran, Jatinangor, West Java, Indonesia, \\ 45363.
}

*Corresponding Author: danar.dono@unpad.ac.id

\begin{abstract}
One of the potential plants to be developed as insecticide is Barringtonia asiatica (Lecythidaceae). Phytochemicals of the same species plant is different in different place and time. This research was conducted to determine toxicity methanolic seed extract of Barringtonia asiatica from different field in Java i.e. Pangandaran, Sindangkerta, Bandung, Jatinangor, and Yogyakarta against Spodoptera litura. The evaluation of toxicity was carried out using feeding method. The result indicated that seed extract of B. asiatica showed value of toxicity from higher to lower were extract of B.asiatica from Pangandaran, Jatinangor, Sindangkerta, Bandung, and Yogyakarta respectively. The extract of B. asiatica showed rendement from higer to lower were extract of B.asiatica from Pangandaran (37.8\%), Sindangkerta (36.1\%), Yogyakarta (29.3\%), Bandung (26.5\%) and Jatinagor (25.8\%). Methanolic seed extract of B.asiatica from Pangandaran showed the highest toxicity and rendement compared from the other place, with $\mathrm{LC}_{50}$ at $0.53 \%$. In addition of toxic property, the extract of $B$. asiatica seed decreased of leaf consumption and pupal weight and lenghtened development time of tested larvae.
\end{abstract}

Keywords: Biology, extract, toxicity, Barringtonia asiatica, Spodoptera litura

\author{
ABSTRAK \\ Toksisitas Ekstrak Methanol Barringtonia Asiatica L (Kurz.) (Lecythidaceae) Dari Tempat Berbeda Di Indonesia \\ Terhadap Spodoptea litura F (Lepidoptera : Noctuidae)
}

Salah satu tanaman potensial untuk dikembangkan sebagai insektisida adalah Barringtonia asiatica (Lecythidaceae). Phytochemical pada tanaman spesies yang sama akan berbeda di tempat dan waktu berbeda. Penelitian ini dilakukan untuk mengetahui toksisitas ekstrak metanol biji Barringtonia asiatica dari berbagai tempat di Jawa yaitu Pangandaran, Sindangkerta, Bandung, Jatinangor, dan Yogyakarta terhadap Spodoptera litura. Evaluasi toksisitas dilakukan dengan menggunakan metode feeding assay. Hasil penelitian mengindikasikan bahwa ekstrak biji $B$. asiatica menunjukkan nilai toksisitas dari yang lebih tinggi ke yang lebih rendah masing-masing yaitu ekstrak B.asiatica dari Pangandaran, Jatinangor, Sindangkerta, Bandung, dan Yogyakarta. Ekstrak B. asiatica menunjukkan rendemen dari yang lebih tinggi ke yang lebih rendah adalah ekstrak B.asiatica dari Pangandaran (37,8\%), Sindangkerta $(36,1 \%)$, Yogyakarta $(29,3 \%)$, Bandung $(26,5 \%)$ dan Jatinagor (25,8\%). Ekstrak methanol biji B.asiatica dari Pangandaran menunjukkan toksisitas dan rendemen tertinggi dibandingkan dengan tempat lain, dengan $\mathrm{LC}_{50}$ sebesar $0,53 \%$. Selain sifat beracun, ekstrak biji B. asiatica menurunkan konsumsi daun pakan dan berat pupa dan waktu perkembangan yang lebih lama dari larva yang diuji.

Kata kunci: Ekstrak, biologi, toksisitas, Barringtonia asiatica, Spodoptera litura

\section{PENDAHULUAN}

Tumbuhan mengandung berbagai macam senyawa kimia metabolit sekunder yang berperan sebagai sebagai senyawa pertahanan terhadap organisme pengganggunya. Telah diketahui terdapat 2121 spesies tanaman yang sudah dilaporkan dapat berpotensi sebagai insektisida nabati (Mamun \& Ahmed, 2011). Indonesia adalah salah satu negara yang memiliki keberagaman tumbuhan yang tinggi. Banyak diantaranya merupakan sumber bahan insektisida yang dapat dimanfaatkan untuk pengendalian hama.

Sejalan dengan konsep PHT, pemanfaatan insektisida nabati menjadi salah satu alternatif pengendalian yang potensial untuk dikembangkan karena mudah terurai (highly biodegradable) di alam, serta relatif aman bagi manusia dan lingkungannya (Prasannath, 2016). Salah satu tumbuhan yang berpotensi untuk dikembangkan sebagai sumber insektisida botani adalah Barringtonia asiatica (L) . dari kelompok saponin yang diisolasi dari ekstrak metanol biji B. asiatica bersifat antifeedant terhadap larva Epilachna (Herlt et al., 2005).

Ekstrak metanol biji B.asiatica memiliki aktivitas insektisida pada larva Crossidolomia pavonana $\mathrm{LC}_{50}$ dengan konsentrasi $0,7 \%$, terhadap kematian larva $C$. pavonana instar dua sampai instar empat (Dono \& Sujana, 2007). Ekstrak B. asitica juga memiliki aktivitas insektisida pada larva Spodoptera litura (ulat grayak) dengan konsentrasi $\mathrm{LC}_{50} 0,30 \%$, terhadap kematian larva S.litura instar satu sampai instar empat (Dono et al., 2012).

Setiap spesies tanaman membutuhkan persyaratan tempat tumbuh yang berbeda agar dapat tumbuh dan berproduksi secara optimal. Dalam pertumbuhan tanaman, seringkali terjadi keragaman dalam satu jenis pohon, yang disebabkan oleh perbedaan lingkungan (environmental variation). $B$. 
asiatica adalah spesies tanaman yang banyak di daerah pantai, namun belakangan diketahui bahwa $B$. asiatica ini juga ditemukan terdapat di beberapa daerah dataran yang jauh dari pantai, hal ini dikarenakan pohon B.asiatica banyak digunakan menjadi tanaman penghijauan. Diantaranya B.asiatica terdapat di lapangan Gasibu kota Bandung, Jatinangor, dan lapangan kraton Yogyakarta.

Dengan adanya tanaman $B$. asiatica di beberapa daerah sebagai tempat tumbuh tanaman tersebut dan memiliki perbedaan disetiap tempatnya akan berpengaruh terhadap jumlah rendemen ekstrak yang dihasilkan dan tingkat toksisitas ekstrak biji $B$. Asiatica . Oleh karena itu, ekstrak biji B. Asiatica dari derah Pangandaran, Sindangkerta, Gasibu (Bandung), Yogyakarta dan Jatinangor perlu diuji untuk mengetahui tingkat toksisitasnya terhadap Spodoptera litura

\section{BAHAN DAN METODE}

\section{Penyediaan larva Spodoptera litura}

Larva $S$. litura diperoleh dari tanaman sawi yang terserang $S$. litura di kecamatan Cikajang Kabupaten Garut diperbanyak dalam kotak plastik berukuran $34 \mathrm{~cm}$ x $28 \mathrm{~cm}$ x $7 \mathrm{~cm}$ yang dialasi dengan kertas tissue agar kotak plastik tidak terlalu basah. Alas kertas tissue diganti setiap hari saat pemberian makan larva. Larva diberi pakan daun talas. Pada saat larva akan membentuk pupa wadah pemeliharaan diberi tanah steril untuk pembentukan pupa. Imago yang muncul dari pupa dipelihara dalam kurungan plastik - kasa berukuran $50 \mathrm{~cm}$ x $50 \mathrm{~cm}$ x $50 \mathrm{~cm}$ dan diberi pakan cairan madu $10 \%$ yang diserapkan pada segumpal kapas.

Tempat peletakan telur yang digunakan yaitu daun talas yang dimasukkan ke dalam kurungan imago. Kelompok telur yang diletakkan pada daun talas dikumpulkan dan dimasukkan ke dalam wadah plastik berventilasi berukuran $10 \mathrm{~cm}$ x $6,5 \mathrm{~cm}$ x 4,5 $\mathrm{cm}$ yang telah dilapisi kertas tissue.

\section{Penyediaan ekstrak biji $B$. Asiatica}

Biji B. asiatica diperoleh dari Pangandaran Kabupaten Ciamis, Sindangkerta Kabupaten Tasikmalaya, Gasibu Kabupaten Bandung, Yogyakarta dan Jatinangor Kabupaten Sumedang. Biji dipotong-potong sepanjang $1-2 \mathrm{~cm}$, kemudian dikering anginkan selama kurang lebih 1 minggu, biji yang sudah kering dihaluskan dengan cara diblender dan disaring dengan ayakan. Serbuk hasil ayakan diekstraksi dengan pelarut metanol dengan perbandingan $1: 10(\mathrm{w} / \mathrm{v})$. Bahan serbuk biji direndam selama 3 hari, selanjutnya disaring menggunakan kertas saring. Pembilasan serbuk biji dilakukan sebanyak tiga kali. Hasil penyaringan di evaporasi menggunakan rotary evaporator (IKA.WERKE HB4 Basic, tipe D-79219) pada suhu 55-60 ${ }^{\circ} \mathrm{C}$ dan tekanan rendah. Ekstrak yang diperoleh disimpan di dalam lemari es pada suhu $\pm 4^{\circ} \mathrm{C}$ dan dikeluarkan pada saat dibutuhkan untuk melakukan pengujian.

Penghitungan rendemen ekstrak biji B.asiatica dilakukan dengan menggunakan rumus :

$$
\text { rendemen }=\frac{\text { bobot hasil ekstraksi }}{\text { bobot kering serbuk biji }} \times 100 \%
$$

\section{Screening toksisitas B.asiatica dari beberapa daerah.}

Screening ekstrak biji B.asiatica yang diperoleh dari lima daerah berbeda yaitu asal daerah Pangandaran, Sindang kerta, Jatinangor, Bandung, dan Jogjakarta. Konsentrasi ekstrak biji yang diuji yaitu $0,1 \%$ dan $0,5 \%$. Pengujian dimaksudkan untuk mengetahui daerah asal B.asiatica yang ekstrak bijinya mengakibatkan kematian serangga uji paling tinggi. Pengujian dilakukan terhadap ulat $S$. litura instar I dengan perlakuan pakan serangga uji (feeding method).

Setiap larutan yang akan diuji dibuat dengan cara ekstrak metanol biji B.asiatica dilarutkan dengan aquades yang telah ditambah agristik sebagai perekatperata dengan konsentrasi 0,25 $\mathrm{ml} / \mathrm{l}$. Perlakuan ekstrak dilakukan dengan cara pencelupan daun talas ukuran $4 \mathrm{~cm} \mathrm{x} 4 \mathrm{~cm}$ ke dalam masing-masing larutan ekstrak selama 1 menit dan dikeringanginkan. Selanjutnya daun dimasukkan ke dalam cawan petri yang telah dialasi kertas hisap. Kedalam setiap cawan petri yang telah berisi daun perlakuan dimasukkan 10 larva $S$. litura instar I dengan menggunakan kuas halus. Pemberian pakan daun perlakuan dilakukan selama 72 jam ( 3 x 24 jam), selanjutnya larva diberi pakan daun tanpa perlakuan ekstrak.

Peubah yang diamati yaitu mortalitas larva uji, bobot pupa dan luas konsumsi pakan. Pengukuran bobot pupa dilakukan dengan menimbang bobot pupa $S$. litura yang terbentuk dari larva yang bertahan hidup. Data bobot pula di analisis secara statistik menggunakan program SPSS 16.

Pengukuran luas daun yang dikonsumsi larva dilakukan dengan menghitung luas daun yang dikonsumsi $S$. litura menggunakan kertas milimiter blok. Pengukuran luas daun dilakukan saat awal dan setelah daun dikonsumsi larva pada hari ke-2 setelah pemberian pakan pada larva uji.

\section{Toksisitas ekstrak metanol biji B. asiatica. terhadap larva $S$. litura \\ Ekstrak biji $B$. asiatica yang memiliki} toksisitas tertinggi hasil uji screening kemudian di uji lebih lanjut untuk menentukan nilai toksisitasnya. Pengujian terdiri atas uji pendahuluan dan uji lanjutan. Uji pendahuluan dilaksanakan dengan menggunakan lima seri konsentrasi awal berdasarkan uji screening dengan konsentrasi $0,1 \%, 0,3 \%, 0,5 \%$, $0,7 \%$ dan $0,8 \%$. Lima seri konsentrasi awal tersebut diuji untuk menentukan batas atas dan batas bawah konsentrasi uji yang akan digunakan pada uji lanjutan. Pengujian lanjutan dilakukan menggunakan lima taraf 
konsentrasi dan kontrol yang mengakibatkan kematian serangga uji antara $0<\mathrm{y}<100 \%$. Lima seri konsentrasi tersebut ditentukan berdasarkan interval geometris. Setiap perlakuan dalam percobaan ini diulang sebanyak 3 kali dan mortalitas larva dicatat dengan cara yang sama dengan uji sebelumnya.

Perhitungan seri konsentrasi yang akan digunakan dengan interval geometris adalah sebagai berikut :

$$
\begin{aligned}
& \mathrm{A}=\operatorname{anti} \log \mathrm{F} \\
& \mathrm{F}=\sqrt[n-1]{\frac{\mathrm{LC}_{90}}{\mathrm{LC}_{10}}}
\end{aligned}
$$

Keterangan :

$\mathrm{A}=$ Interval geometris

$\mathrm{F}=$ Faktor penambah/kenaikan

$\mathrm{n}=$ Jumlah log konsentrasi

Percobaan dilakukan dengan cara pencelupan makanan, makanan yang digunakan yaitu daun talas. Larutan ekstrak yang akan diuji dibuat dengan cara ekstrak metanol biji $B$. asiatica dengan bobot tertentu sesuai konsentrasi uji dilarutkan dengan aquades yang telah ditambah agristik sebagai perekat-perata dengan konsentrasi 0,25 ml/1. Larutan tersebut diaplikasikan dengan cara mencelupkan beberapa potongan daun talas berukuran $4 \mathrm{~cm} \times 4 \mathrm{~cm}$ selama beberapa detik hingga kedua permukaan daun terbasahi larutan ekstrak secara merata, kemudian daun pakan tersebut dikeringanginkan di atas kertas buram. Daun yang telah diberi perlakuan tersebut lalu diletakkan di dalam petridish yang diberi alas kertas tissue. Larva $S$. litura instar II sebanyak 10 ekor dimasukkan ke dalam setiap cawan petri dengan menggunakan kuas nomor 3. Pemberian pakan daun perlakuan dilakukan selama 72 jam (3 x 24 jam), selanjutnya larva diberi pakan daun tanpa perlakuan hingga mencapai instar IV.

Peubah yang diamati yaitu mortalitas larva $S$. litura sejak instar I sampai dengan instar IV. Mortalitas S. litura dihitung menggunakan rumus :

$$
\begin{aligned}
& \text { Mortalitas (\%) } \\
& =\frac{\text { Jumlah } \text { S. litura yang mati }}{\text { Jumlah } \text { S. litura yang diuji }} \times 100 \%
\end{aligned}
$$

Apabila pada kontrol terdapat $S$. litura yang mati kurang dari $20 \%$ maka data yang diperoleh dapat dikoreksi dengan menggunakan rumus Abbots sebagai berikut :

Keterangan :

$$
\operatorname{Pt}(\%)=\frac{P o-P c}{100-P c} \times 100 \%
$$

$\mathrm{Pt}=$ Persentase mortalitas serangga uji yang telah dikoreksi

Po $=$ Persentase mortalitas serangga uji karena perlakuan

Pc $\quad=$ Persentase mortalitas serangga uji pada kontrol
Data mortalitas yang didapat dari setiap konsentrasi yang diuji digunakan sebagai dasar dalam penentuan $\mathrm{LC}_{50}$ dengan menggunakan analisis probit program POLO-PC Loera. Selain itu dilakukan pengamatan terhadap kelembaban udara (\%) dan temperatur udara $\left({ }^{\circ} \mathrm{C}\right)$ dalam ruangan tempat melakukan percobaan dengan menggunakan alat thermohigrometer.

\section{HASIL DAN PEMBAHASAN}

\section{Rendemen ekstrak biji B.asiatica}

Rendemen ekstrak biji B. asiatica (Tabel 1) yang paling banyak dihasilkan oleh ekstrak asal daerah Pangandaran yaitu sebesar 29,87\%. Meskipun rendemen ekstrak B.asiatica asal daerah Pangandaran dan asal daerah Sindangkerta tidak berbeda jauh dan pendapat ini sesuai dengan tanaman $B$. asiatica yang merupakan tanaman yang banyak tumbuh di pesisir pantai.

Tabel 1. Persentase rendemen enam daerah B.asiatica.

\begin{tabular}{lc}
\hline \multicolumn{1}{c}{ Asal Daerah } & $\begin{array}{c}\text { Rendemen } \\
(\%)\end{array}$ \\
\hline Jatinagor & 25,79 \\
Bandung & 26,47 \\
Sindangkerta & 36,11 \\
Pangandaran & 37,77 \\
Yogyakarta & 29,31 \\
\hline
\end{tabular}

\section{Pengaruh Ekstrak Metanol Biji B. asiatica Terhadap Mortalitas larva}

Hasil pengujian diperoleh satu ekstrak asal daerah yang memiliki nilai mortalitas lebih tinggi dibandingkan dengan daerah lainnya, yaitu ekstrak asal daerah Pangandaran. Tabel 2 menunjukkan mortalitas larva $S$. litura yang diuji dengan ekstrak asal daerah Pangandaran pada saat larva mencapai instar IV dengan konsentrasi $0,1 \%$ adalah sebesar $27,5 \%$ dan konsentrasi $0,5 \%$ sebesar $50 \%$.

Larva $S$. litura yang mendapat perlakuan ekstrak metanol biji $B$. asiatica memiliki ukuran tubuh lebih kecil dibandingkan dengan ukuran tubuh larva pada kontrol, selain itu larva mengalami penghambatan untuk berkembang pada instar selanjutnya. Perbedaan ukuran larva akibat proses terhambatnya aktivitas makan dan terhambatnya pertumbuhan dan perkembangan larva. Larva yang telah mati menunjukkan gejala mengering dan berwarna kehitaman. Ekstrak biji $B$. asiatica mengandung senyawa saponin yang menyebabkan terhambatnya aktivitas makan serangga, kematian, dan penghambat tumbuh (Maharani et al., 2009; Geyter et al., 2007).

Insektisida akan masuk ke organ pencernaan serangga dan diserap oleh dinding usus kemudian ditranslokasikan ke tempat sasaran yang mematikan sesuai dengan mekanisme kerja bahan aktif insektisida. Terganggunya proses pergantian kulit akibat pemberian ekstrak $B$. asiatica di duga karena 
kandungan saponin dalam ekstrak tersebut. Terdapatnya senyawa saponin akan mengikat sterol pada saluran pencernaan makanan (Gershenzon dan Croteu, 1991). Pengikatan sterol dalam pencernaan makanan akan menurunkan sterol dalam hemolimpa. Peran penting sterol bagi serangga adalah sebagai precursor dari hormon ekdison, sehingga dengan menurunnya persediaan sterol maka proses pergantian kulit pada serangga juga akan tergangu. Senyawa alkaloid yang terdapat pada $B$. asiatica dapat menyebabkan iritasi pada saluran pencernaan dengan merusak membrane peritrofik saluran pencernaan larva uji (Pyensor, 1980).

Pengaruh Ekstrak Metanol Biji B. asiatica Beberapa daerah Terhadap Bobot Pupa S.litura Pengaruh ekstrak metanol enam daerah B.asiatica. terhadap bobot pupa $S$. litura menunjukkan hasil yang beragam. Bobot pupa pada kontrol lebih tinggi dibanding dengan bobot seluruh larva yang diberi perlakuan ekstrak yaitu 0,272 gram. Larva $S$. litura yang diuji dengan ekstrak metanol biji B.asiatica asal daerah Pangandaran pada konsentrasi $0,5 \%$ memiliki bobot paling rendah dibanding dengan bobot larva uji lainnya, yaitu sebesar 0,102 gram (Tabel 3.).

Tabel 2. Persentase mortalitas larva S. litura pada uji screening toksisitas ekstrak metanol biji B.asiatica.

\begin{tabular}{lcc}
\hline Asal Daerah & Konsentrasi $(\%)$ & $\begin{array}{c}\text { Mortalitas } \\
(\%)\end{array}$ \\
\hline Jatinagor & 0,1 & $22.5 \mathrm{de}$ \\
Bandung & 0,5 & $40 \mathrm{f}$ \\
& 0,1 & $10 \mathrm{a}$ \\
Sindangkerta & 0,5 & $27.5 \mathrm{~cd}$ \\
Pangandaran & 0,1 & $25 \mathrm{e}$ \\
Yogyakarta & 0,5 & $35 \mathrm{bc}$ \\
Kontrol & 0,1 & $27.5 \mathrm{~cd}$ \\
& 0,5 & $50 \mathrm{f}$ \\
& 0,1 & $12.5 \mathrm{ab}$ \\
& 0,5 & $20 \mathrm{bc}$ \\
\end{tabular}

Tabel 3. Pengaruh ekstrak metanol biji B. asiatica terhadap bobot pupa S. litura

\begin{tabular}{lccc}
\multicolumn{1}{c}{ Asal Daerah Tanaman } & Konsentrasi (\%) & Bobot Pupa (gram) & $(\mathrm{N})$ \\
\hline \multirow{2}{*}{ Jatinagor } & 0,1 & $0,196 \pm 0,012 \mathrm{abc}$ & $(8)$ \\
& 0,5 & $0,271 \pm 0,017 \mathrm{bc}$ & $(3)$ \\
Bandung & 0,1 & $0,111 \pm 0,110 \mathrm{a}$ & $(4)$ \\
Sindangkerta & 0,5 & $0,109 \pm 0,109 \mathrm{a}$ & $(6)$ \\
& 0,1 & $0,197 \pm 0,004 \mathrm{abc}$ & $(4)$ \\
Pangandaran & 0,5 & $0,222 \pm 0,001 \mathrm{abc}$ & $(5)$ \\
Yogyakarta & 0,1 & $0,175 \pm 0,022 \mathrm{abc}$ & $(3)$ \\
Kontrol & 0,5 & $0,102 \pm 0,088 \mathrm{abc}$ & $(4)$ \\
\hline \multicolumn{1}{c}{ Keterangan $: \mathrm{N}=$ jumlah pupa } & 0,1 & $0,219 \pm 0,129 \mathrm{ab}$ & $(16)$ \\
\hline
\end{tabular}

Keterangan : $\mathrm{N}=$ jumlah pupa

Angka yang diikuti huruf yang sama dalam kolom yang sama tidak berbeda nyata menurut uji Duncan

Pembentukan pupa pada serangga dipengaruhi oleh pemenuhan jumlah nutrisi yang dibutuhkan oleh serangga ketika fase larva. Penurunan aktivitas makan pada serangga akibat senyawa toksik, dapat menyebabkan kegagalan dalam pembentukan pupa (Adel et al., 2000). Penurunan bobot pupa merupakan satu kompensasi karena terjadinya ganguan pada serangga uji, hal ini terjadi karena larva mengkonsumsi pakan yang kurang optimal, yang disebabkan pakan mengandung senyawa alkaloid akibatnya terjadi gangguan pada pertumbuhan dan perkembangannya. Pada larva yang bertahan hidup dan berhasil membentuk pupa terjadi gangguan metabolisme sehingga asupan nutrisi terganggu pada saat larva, sehingga mengakibatkan waktu perkembangannya menjadi lebih lama. Gangguan metabolisme dan fisiologi tersebut juga mengakibatkan ketidaknormalan pembentukan pupa dan akhirnya mati (Geyter et al., 2007).

\section{Pengaruh Ekstrak Metanol Biji B. asiatica terhadap Luas Daun Yang Dikonsumsi Larva Spodoptera litura}

Setiap perlakuan menyebabkan perbedaan persentase luas daun yang dimakan oleh larva $S$. litura. Data tersebut menunjukkan bahwa pada perlakuan ekstrak B.asiatica pada semua konsentrasi telah terjadi penghambatan aktivitas makan bila dibandingkan dengan kontrol yaitu dengan jumlah daun yang dimakan pada 2 HSA dan 4 HSA rata-rata sebesar $23,6 \%$ dan $33,3 \%$, yang diakibatkan oleh pengaruh senyawa aktif yang terdapat pada ekstrak 
metanol biji $B$. asiatica, sehingga menyebabkan persentase rata-rata luas daun yang dimakan oleh serangga uji pada beberapa konsentrasi terlihat menurun. Persentase rata-rata luas daun yang dimakan larva pada 2 HSA tidak berbeda jauh, namun dari hasil tersebut dapat terlihat bahwa luas daun yang dimakan yang persentasenya lebih sedikit dari yang lainnya adalah luas daun yang diberi perlakuan ekstrak B.asiatica asal daerah
Pangandaran pada konsentrasi $0,1 \%$ dengan rata-rata luas daun yang dimakan 14\%, dan konsentrasi $0,5 \%$ dengan rata-rata luas daun yang dimakan 4,6\%. Pada 4 HSA perbedaan luas daun yang dimakan oleh larva mengalami kenaikan, namun dari hasil tersebut dapat terlihat luas daun yang paling sedikit dimakan yaitu daun yang diberi perlakuan ekstrak $B$. asiatica dari daerah Pangandaran dan Sindangkerta (Tabel 4).

Tabel 4. Pengaruh ekstrak biji $B$. asiatica terhadap persentase rata-rata luas daun yang dikonsumsi larva $S$. litura

\begin{tabular}{lcc}
\hline $\begin{array}{l}\text { Asal Daerah } \\
\text { B. asiatica }\end{array}$ & Konsentrasi ekstrak (\%) & $\begin{array}{c}\text { Luas daun yang dikonsumsi (\%) } \\
\text { pada 2 HSA }(\%)\end{array}$ \\
\hline & & $16,6 \mathrm{c}$ \\
Jatinangor & 0,1 & $7,6 \mathrm{~b}$ \\
& 0,5 & $14,0 \mathrm{c}$ \\
Bandung & 0,1 & $6,0 \mathrm{ab}$ \\
& 0,5 & $15,3 \mathrm{c}$ \\
Sindangkerta & 0,1 & $6,0 \mathrm{ab}$ \\
& 0,5 & $14,0 \mathrm{c}$ \\
Pangandaran & 0,1 & $4,6 \mathrm{a}$ \\
& 0,5 & $14,6 \mathrm{c}$ \\
Yogyakarta & 0,1 & $7,0 \mathrm{ab}$ \\
Kontrol & 0,5 & $23,6 \mathrm{~d}$ \\
\hline
\end{tabular}

Keterangan : Angka yang diikuti huruf yang sama dalam kolom yang sama tidak berbeda nyata menurut uji Duncan. HSA $=$ Hari Setelah Aplikasi

Luas daun yang dikonsumsi oleh larva $S$. litura pada perlakuan ekstrak methanol $B$. asiatica asal Pangandaran terlihat lebih sedikit dibandingkan dengan perlakuan kontrol (Gambar 1. dan Tabel 4.). Hal ini dimungkinkan karena telah terjadi penghambatan aktivitas makan. Beberapa peneliti melaporkan bahwa saponin menyebabkan berkurangnnya aktivitas makan serangga, karena dalam semua kasus yang terjadi serangga akan lebih dahulu memakan daun tanaman yang sudah diberi perlakuan sebelum menolaknya (Adel et al., 2000).

Senyawa aktif yang terdapat dalam ekstrak metanol biji $B$. asiatica bersifat antifeedant dapat mematikan serangga uji secara tidak langsung. Terganggunya aktivitas makan inilah yang menyebabkan pasokan nutrisi yang dibutuhkan oleh tubuh serangga menjadi menurun dan dapat menyebabkan kematian pada serangga tersebut. Senyawa aktif berupa saponin yang terkandung dalam ekstrak metanol biji $B$. asiatica diduga memiliki efek sebagai antifeedant. Senyawa saponin dapat menurunkan aktifitas enzyme protease dalam saluran pencernaan serangga sehingga mempengaruhi proses penyerapan makanan, akibatnya makanan yang masuk tidak dapat diserap dan langsung di keluarkan dalam bentuk feses (Gershenzon \& Croteu, 1991). Kondisi tersebut sejalan dengan temuan Herlt et al. (2002) yang menunjukkan saponin utama yang diisolasi dari $B$. asiatica memiliki aktivitas anifeedant pada Epilachna.
Dari analisis hasil tersebut di atas maka dapat disimpulan bahwa ekstrak biji B.asiatica asal daerah Pangandaran akan dipelajari lebih lanjut toksisitasnya terhadap larva $S$. litura. Ekstrak asal daerah Pangandaran tersebut dipilih karena menyebabkan mortalitas paling tinggi yaitu pada konsentrasi $0,1 \%$ sebesar $27,5 \%$ dan konsentrasi $0,5 \%$ sebesar $50 \%$, memiliki nilai rendemen paling tinggi yaitu sebesar $29,87 \%$, memilliki bobot pupa rata-rata paling rendah pada konsentrasi 0,5 sebesar 0,102 gram, selain itu memiliki rata-rata luas daun yang dimakan paling sedikit pada 2 HSA konsentrasi $0,5 \%$ sebesar $4,6 \%$ dan $12 \%$, pada kondisi percobaan rata- rata suhu $26,12^{\circ} \mathrm{C}$ dan kelembapan $80,18 \%$.

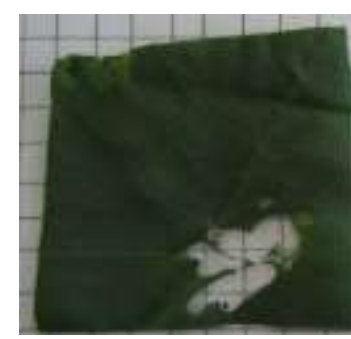

A

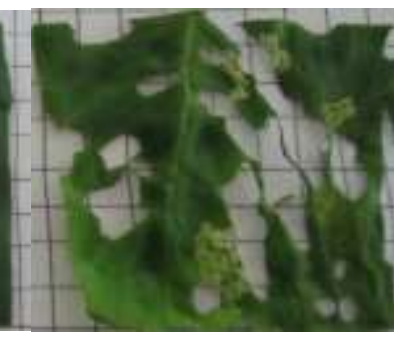

B
Gambar 1. Pengaruh ekstrak metanol biji B. asiatica terhadap luas daun yang dikonsumsi. (A) Luas daun yang dimakan pada konsentrasi $0,5 \%$ asal daerah Pangandaran, (B) luas daun yang dimakan pada kontrol. 
Toksisitas ekstrak metanol biji $B$. asiatica asal Daerah Pangandaran terhadap larva $S$. litura

Kematian larva terjadi pada pengamatan hari ke dua setelah aplikasi pada saat larva mengalami pergantian kulit untuk berganti instar hingga larva berubah menjadi pupa. Peningkatan mortalitas yang cukup tinggi pada hari ke-7, pada saat larva mulai memasuki instar IV setelah aplikasi. Konsentrasi 0,16 $\%$ menyebabkan mortalitas sebesar $20 \%$, konsentrasi $0,32 \%$ sebesar $27,5 \%$, konsentrasi $0,48 \%$ sebesar $35 \%$, konsentrasi $0,64 \%$ sebesar $47,5 \%$, dan konsentrasi $0,80 \%$ sebesar $77,5 \%$. Mortalitas larva masih meningkat hingga larva mencapai masa prapupa (Gambar 2.).

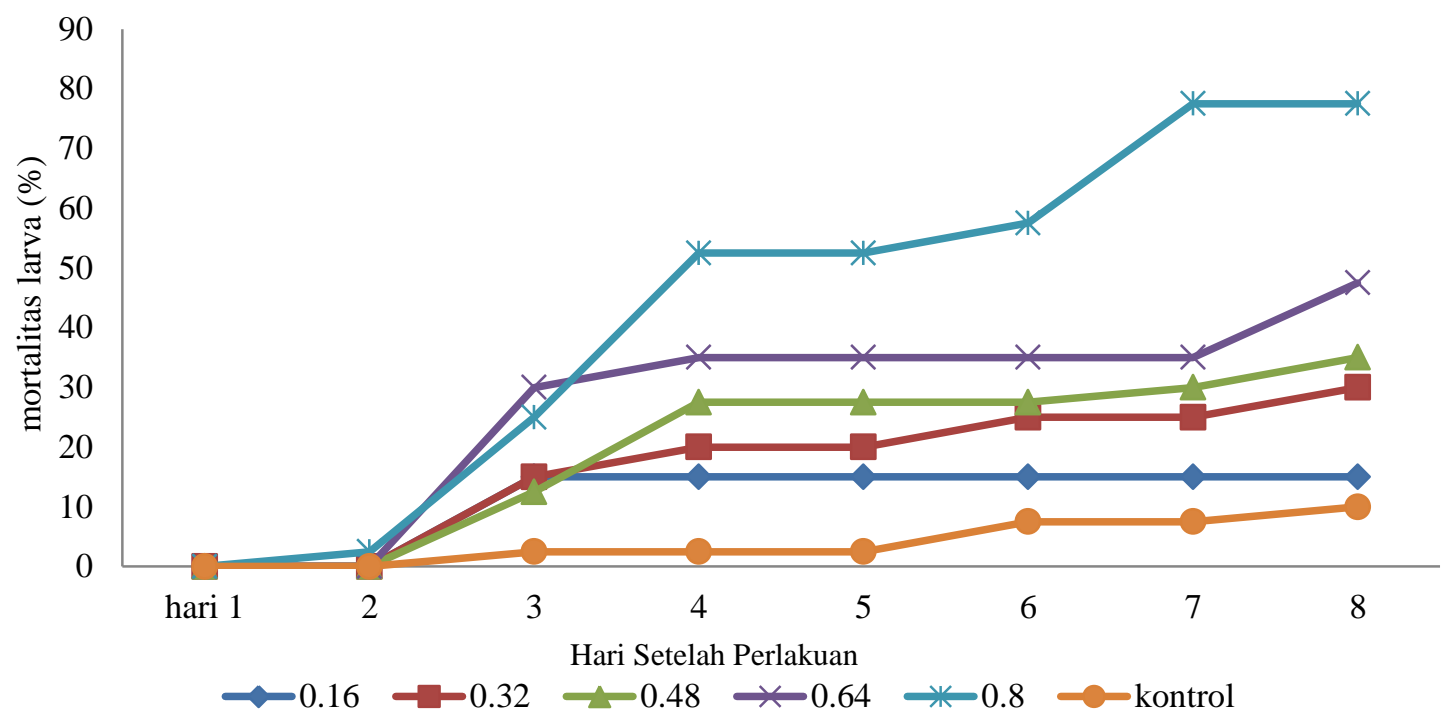

Gambar 2. Mortalitas larva S. litura setelah perlakuan ekstrak biji B. asiatica

Tabel 5. Hasil analisis $\mathrm{LC}_{50}$ pengujian ekstrak methanol biji B.asiatica asal Pangandaran terhadap larva S.litura berdasarkan waktu pengamatan.

\begin{tabular}{ccccccc}
\hline $\begin{array}{c}\text { WP } \\
(\text { HSA })\end{array}$ & B \pm SE & $\begin{array}{c}\text { Nilai } \\
\text { LC50 } \\
(\%)\end{array}$ & $\begin{array}{c}\text { Batas } \\
\text { Kepercayaan } \\
-95 \%\end{array}$ & $\begin{array}{c}\text { Nilai } \\
\text { LC90 } \\
(\%)\end{array}$ & $\begin{array}{c}\text { Batas } \\
\text { Kepercayaan } \\
-95 \%\end{array}$ & $\mathrm{~g}$ \\
\hline 3 & $0,768 \pm 0,493$ & 7,285 & & 339,60 & - & 4,25 \\
5 & $1,655 \pm 0,477$ & 1,000 & $2,821-0,704$ & 5,95 & $160,92-5,95$ & 0,320 \\
8 & $3,446 \pm 0,862$ & 0,588 & $0,714-0,498$ & 1,38 & $3,38-1,00$ & 0,241 \\
10 & $3.799 \pm 1,004$ & 0,600 & $0,719-0,512$ & 1,30 & $3,191-0,966$ & 0,268 \\
12 & $3,963 \pm 1,047$ & 0,611 & $0,734-0,523$ & 1,28 & $3,051-0,962$ & 0,268 \\
14 & $4,023 \pm 0,986$ & 0,581 & $0,681-0,496$ & 1,20 & $2,452-0,927$ & 0,231 \\
16 & $3,872 \pm 0,851$ & 0,532 & $0,617-0,451$ & 1,14 & $2,032-0,890$ & 0,18 \\
\hline
\end{tabular}

Keterangan : $\mathrm{WP}=$ waktu pengamatan $\mathrm{g}=$ batas potensi indeks signifikan $\mathrm{HSA}=$ hari setelah aplikasi

Senyawa aktif yang terkandung dalam ekstrak metanol biji $B$. asiatica bekerja secara lambat dengan respon mortalitas yang optimal sebesar $82.5 \%$ pada konsentrasi $0,8 \%$ dapat dicapai pada 16 HSA pada saat larva menuju masa prapupa atau instar VI, masa prapupa ini merupakan masa yang paling rentan untuk S.litura. Hal ini diakibatkan dari cara kerja senyawa aktif yang berupa saponin lebih bersifat sebagai racun perut sehingga tidak menyebab kematian larva secara langsung (Agrell et al. 2004).

Analisis probit dilakukan terhadap data mortalitas pada saat larva berubah instar menjadi instar II sampai dengan larva masuk pada masa prapupa. Peningkatan dan penurunan $\mathrm{LC}_{50}$ terjadi pada saat instar II sampai instar IV. Nilai LC $_{50}$ pada saat semua larva mencapai instar IV yaitu pada 8 hari setelah aplikasi sudah mulai stabil sampai pada masa prapupa. Hal ini diakibatkan oleh mulai stabilnya peningkatan mortalitas pada beberapa konsentrasi sehingga berdampak pada nilai $\mathrm{LC}_{50}$ yang diperoleh. Nilai $\mathrm{LC}_{50}$ pada 16 hari setelah aplikasi atau pada saat larva mencapai masa prapupa setara dengan konsentrasi 0,532\% (Tabel 5).

Nilai $\mathrm{LC}_{50}$ ekstrak methanol $B$. asiatica dari pangandaran ini lebih besar dari pada nilai $\mathrm{LC}_{50}$ hasil penelitian Majid tahun 2011 sebelumnya yaitu $0,30 \%$ hal ini dimungkinkan adanya perbedaan larva uji $S$. litura yang digunakan yaitu larva standar asal balitsa. Sehingga respon yang di timbulkan berbeda karena larva yang digunakan pada penelitian ini adalah larva 
F3 lapangan asal daerah Cikajang Garut, yang mana derah Cikajang tersebut merupakan daerah yang dilaporkan telah terjadi kasus resistensi untuk beberapa bahan aktif insektisida. Sehingga meskipun larva telah di rearing ada kemungkinan masih terdapat efek resistensi dari senyawa yang bersifat insektisidal. Selain dari pada itu waktu dan keadaan suhu dan kelembapan yang berdeda pada saat percobaan dapat menimbulkan respon larva uji yang berbeda.

Berdasarkan hasil analisis $\mathrm{LC}_{50}$ (Tabel 5), ekstrak metanol biji B.asiatica bersifat toksik terhadap larva S.litura. afek antifeedant merupakan salah satu mekanisme utama yang berperan dalam pengendalian hama (Isman, 2002). Dari pernyataan tersebut maka antifidan dapat berupa penolakan makan dengan tidak ada aktivitas makan sama sekali dan penghambatan makan. Dalam hal ini ekstrak metanol biji B.asiatica memberikan efek sementara yaitu penghambatan makan pada larva S. litura.

\section{KESIMPULAN DAN SARAN}

Asal daerah tanaman B. asiatica mempengaruhi toksisitas ekstraknya. Ekstrak methanol biji B.asiatica memiliki nilai toksisitas dari nilai tertinggi ke terendah secara berurutan yaitu ekstrak methanol B.asiatica asal daerah Pangandaran, Jatinangor, Sindangkerta, Bandung, dan Yogyakarta. Tanaman yang memiliki jumlah rendemen ekstrak secara berurutan dari yang terbesar ke yang terkecil adalah B. asiatica dari daerah Pangandaran, Sindangkerta, Jatinangor, Yogyakarta, dan Bandung. Ekstrak methanol biji B.asiatica asal daerah Pangandaran memilki nilai toksisitas dan rendemen tertinggi, dengan nilai LC50 sebesar 0,53\%. Selain bersifat toksik, ekstrak metanol biji $B$. asiatica juga memperlihatkan pengaruh terhadap penurunan bobot pupa, dan juga luas daun yang dimakan.

\section{DAFTAR PUSTAKA}

Adel MM, Sehnal F, \& Jurzysta M . 2000. Effects of alfalfa saponins on the moth Spodoptera littoralis. Journal of Chemical Ecology. 26: 1065-1078

Agrell J, Anderson P, Oleszek W, Stochmal A, Agrell C. 2004. Combined effects of elevated CO2 and herbivore damage on alfalfa and cotton. Journal of Chemical Ecology 30: 2309-2323.
Dono,D. \& N.sunjana. 2007.Aktivitas insektisida ekstrak daun, kulit batang, dan biji barringtonia asiatica (Lecythidaceae) terhadap larva crocidolomia pavonana (Lepidoptera: Pyralidae).disampaikan pada symposium Nasional PEI, Revitalisasi Penerapan PHT dalam praktek Pertanian Yang Baik Menuju Siastem Pertanian Berkalanjutan,Sukamandi 10-11 April 2007.

Dono D, WD. Natawigena, MG. Majid. 2012. Bioactivity of Methanolic Seed Extract Of Barringtonia asiatica L. (Kurz) (Lecythidaceae) On Biological Characters Of Spodotera litura (Fabricius) (Lepidoptera: Noctiudae). International Research Journal of Agricultural Science and Soil Science (IRJAS). November; 2: 465 - 497

Gershenzon, J. \& R. Croteu. 1991 Terpenoid .Pages 165-209. In G.A. Rosental \& M.R Barenbaun. Eds Herbivores their interaction with secondary plant metabolites. $2^{\text {nd }}$ edition academic press. New York.

Geyter ED., Geelen, D., Smasshe G. 2007. First result on the insecticidal action of saponins. Comm. Appl. Biol.Sci. 72(3): 645-648.

Herlt, AJ, LN Mander, POngoh, RJ Rumapuk, \& P Tarigan. 2002. Two major saponins froem seeds of Barringtonia asiatica: putative antifeedants toward Epilachna sp. Larvae. (Abstract). J. Nat Prod. 65 (2):115-120.

Isman, MB. 2002. Insect antifeedants. Pesticides outlook. 1. 152-127. DOI: 10.1039/b206507j

Maharani, R. S. Ishmayana, Y Hidayat, D, Dono. 2009. An Insecticidal compound from Barringtonia asiatica. Sains dan Terapan Kimia. 2(1):48-56.

Mamun MSA. \& M Ahmed. 2011. Prospect of indigenous plant extracts in tea pest management. Int. J. Agril. Res Innov \& Tech. 1(1\&2):16-23.

Prasannath, K. 2016. Botanical insecticides-Special reference to horticultural insect pest management. IJARR. 1(5):14-18.

Pyenson, L. 1980. Fundamental of entomology and plant pathologi. 2nd edition. AVI publishing. AVI Publishing Company, WestportConnecticut.

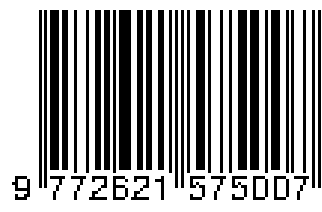

